\title{
Opening up Pedagogies: making a space for children
}

\author{
TERRY WRIGLEY
}

\begin{abstract}
This article argues that children and young people in places such as England or the USA are subjected to an educational regime which constrains their development and eclipses their emergent identities. Paradoxically, the accountability systems which claim to make children's learning visible to management create a distortion of vision by emphasising only the child's 'data shadow'. The article argues for pedagogies which provide space for each learner's authentic encounter with our cultural inheritance as human beings. It concludes by presenting the idea of 'open architectures', a set of pedagogical methods which holds children together as a learning community while providing spaces for initiative.
\end{abstract}

\section{Introduction}

The restricted autonomy and space offered to children as developing human beings is a long-standing feature of traditional schooling (Lawson \& Silver, 1973, pp. 243-246). This principally occurred through processes of physical regimentation: the control of bodily movements and attention, restriction to a limited space, and regimes of classroom communication which effectively limit children's scope to speak except in brief answers to teachers' questions (Sinclair \& Coulthard, 1975). Foucault (1977) referred to the production of 'docile bodies'. Many readers will be familiar with Dickens' satirical presentation in Hard Times, where children's lives are of no significance and knowledge is reduced to verbal definitions.

This tradition of containing children has been reinforced by high-stakes testing and the accountability system in education systems such as England or the USA. Its main vehicle is surveillance through attainment data. This neoTaylorism affects teachers whose salary and indeed employment may depend on test results, but learners too are inscribed with the data of their own performance, as they are categorised, monitored, remediated and pathologised 
(Ball, 2013) in terms of whether they match standardised expectations expressed in numerical terms. Under this neo-liberal regime, even young children are viewed as potential human capital:

More great childcare is vital to ensuring we can compete in the global race, by helping parents back to work and readying children for school and, eventually, employment. (Department for Education [DfE], 2013, p. 5)

This article considers what is happening to children within a regime of highstakes accountability. I will argue that they are being eclipsed, bidden from view, in their essential humanity.

This argument may seem strange at first, given Foucault's well-known argument that we are subject to permanent visibility. Foucault (1977) drew on Jeremy Bentham's model prison, the panopticon, as a metaphor for the technologies of surveillance which enable a few to supervise the many and which penetrate into every corner of our existence. My argument here is that although the assessment and accountability regime exercises tight supervisory control over children, what is actually visible is not the child as a rounded and dynamic being but their data shadow (Roberts-Holmes \& Bradbury, 2016). This can have a seriously distorting effect. Often on the basis of simplistic and misleading assessments, children's 'ability' and 'potential' is delimited from their first weeks in school (see in particular analysis of baseline tests, Reclaiming Schools, 18 January 2016). The aura of scientific accuracy surrounding such tests conveys the belief that 'ability' and 'potential' are measurable quantities. It encourages the common practice of segregating children into 'ability groups', such that the 'lower ability' children often face a debased and demotivating curricular experience.

The child's data shadow can be particularly limiting, therefore, for children with low initial scores, including those growing up in poverty, speakers of other languages, and children with early health problems. It can create a false impression that they have limited capacity to learn, and consequently limits what teachers offer. It can also lead to curricular narrowing, as teachers, as well as parents and nursery staff, are driven to practise very young children for such tests or later resits. This is one of the ways in which social divisions are reproduced by schools.

\section{The Historic Struggle for Child-centred Education}

The process of winning a place for children in their own education took more than two centuries, but is now seriously at risk. It was a protracted, uneven and uphill struggle, with many setbacks. We should not accept the right-wing caricature that 'child-centredness' amounts to simply letting children get on with their own thing - a myth which Dewey $(1938 / 2015)$ himself refutes. Its core principles are that children as people are central to their own learning, and that teachers should work with and not against the developing child. It is 
accompanied by an understanding that you must not divorce mind from body or school learning from the world outside.

This story begins, I believe, with Comenius in the mid-seventeenth century (Adamson, 1971, p. 78) insisting that education starts with mothers, and that primary schools should operate in the mother-tongue, not Latin. We can then trace a line from those who refused to conform to the official state religion after the end of the English Civil War to the Dissenting Academies they set up in the eighteenth century. Key Enlightenment figures such as Joseph Priestley were, characteristically, prominent scientists, political dissidents and popular educators (see, for example, Stewart \& McCann, 1967).

We gain a glimpse of the pedagogy of one dissenting academy in a biography of poet John Keats at the start of the nineteenth century:

One autumn morning, John Ryland called up the whole school to see the departure of the swallows, which had clustered in surprising numbers on the roof of the building ...

Ryland, who believed in educating his pupils 'by recreation', would demonstrate the movements of planets and moons in the solar system ... in the playground. Individual pupils were given a card identifying one of the planets or a moon, and listing some information to be learnt. With their cards, the pupil-planets and moons took up their stations in an appropriate circle of orbit around the classmate representing 'the great Sun'. The 'living orrery' was then set in motion. (Roe, 1997, pp. 29-36)

Set in motion ... Pupil-planets ... The children are right in the middle of their science, they are a part of the action.

A major inspiration of nineteenth-century reformers such as Robert Owen, at New Lanark, and James Kay-Shuttleworth, founder of the first teacher training colleges, was the practice developed by Pestalozzi in his experimental schools in Switzerland (Stewart \& McCann, 1967). Pestalozzi is best known for his holistic belief in 'learning by heart, hand and head'. His work of rethinking education was continued by Froebel, whose key principles included:

- paying attention to the developmental process of the child;

- recognizing the educational value of play;

- a direct experience of nature;

- learning based on activity rather than loading children with facts;

- the child as creative and productive, not simply receptive;

- the importance of free activity, especially in the infant stage (Bowen, 1903; Lawrence, 1969).

Rejecting the word 'school' for young children, he eventually settled on Kindergarten - a children's garden. The name stuck (Bowen, 1903, p. 33).

Froebel often spoke of learning through self-activity. This did not mean (as 'child-centred education' is often caricatured by its enemies) that no teaching is 
needed, but that the teacher's role is to support a child's own activity, to awaken their natural powers:

If, for instance, we desire to further the development of a plant, what we have to do is to induce the plant (and the whole of it) to become active in its own natural way, and to help it to sustain that activity. We may abridge the time; we may modify the results; but we must act through and by the plant's own activity. (Bowen, 1903, p. 49)

The heavy hand of the state, and particularly the system of 'payment by results', created a dark age for English schooling (Lawson \& Silver, 1973, p. 288), but in the early twentieth century Froebel's ideas were taken up by pioneers such as Margaret McMillan, and countless teachers qualified for nursery teaching through a Froebel-based diploma (Lawrence, 1969). Despite the caricatures drawn by reactionaries, 'child-centredness' and 'learning through experience' are not some feel-good, shallow, ineffective wallowing, but ideas and practices which are constantly enriched by close attention to the learner's voice and interactions with adults. For Dewey and Vygotsky, the two giants of twentiethcentury pedagogy, a focus on the child certainly did not involve neglecting established learning or academic disciplines. The child's experience versus knowledge accumulated from our culture is a false dualism for both these theorists:

Instruction ... is a continuous reconstruction, moving from the child's present experience out into that represented by the organised bodies of truth that we call studies. (Dewey, 1902/1966, pp. 126-127)

Similarly, Vygotsky explicitly rejected the botanic metaphor of 'growth', emphasising throughout his work the relationship between the developing child and the cultural heritage of organised knowledge (Vygotsky, 1978, pp. 19-20).

\section{Reinventing Child-centred Pedagogies}

It is essential to keep child-centred and experiential practices alive in the neoliberal epicentre which England has become, and with a particular urgency given the crisis in the current National Curriculum. This neo-conservative curriculum turns its back on the child's identity and experience, regarding knowledge as a fixed corpus of accumulated facts. In this view, technical skills in English are divorced from intentional communication and expression, and 'grammar' is divorced from meaning. Disregarding the language development of very young children, the curriculum documents assume that competence cannot be reached without the prior learning of rules (Wrigley, 2014; Reclaiming Schools, 29 April 2016).

There is no space here to present the range of pedagogies which we can draw upon as resources of resistance. Some rich examples are to be found in a book I helped to edit, Changing Schools (Wrigley et al, 2012). The case studies include accounts of: 
- a Norwegian secondary school that draws heavily on project method and storyline;

- a Chicago school where maths is a tool for examining social inequalities;

- schools run by the Brazilian Landless Workers' Movement;

- a Birmingham nursery school inspired by Reggio Emilia; and place-based learning in various settings.

This is not, of course, the only source of alternatives.

I am particularly interested, however, in pedagogies which have (i) a broad structure, spanning well beyond the 40 -minute lesson, to sustain the class as a learning community, but a structure with (ii) open spaces in which learners are encouraged to take initiatives. I have called these open architectures (Wrigley, 2005, 2007). We can consider as examples making a video; simulation games; collective design and technology projects with a social purpose; Mantle of the Expert (Heathcote \& Bolton, 1995), to name a few.

My interest was first aroused by the use of project method for citizenship in Danish schools, and by the Scottish invention of Storyline for lower primary though used extensively with adolescents and young adults in Scandinavia. Project method, as used in social studies and citizenship lessons in Denmark (Undervisningsministeriet 1995), has the following structure:

1. a theme or issue suggested by either the teacher or students - the whole class becomes engaged;

2. a plenary discussion of issues, problems and ideas, including the learners' experience and knowledge and the potential contribution of knowledge and skills from academic disciplines;

3. group or individual research on a sub-theme of their choice;

4. research groups present to the class to engage them in further discussion.

This can be followed by a real-world outcome, such as social action or presentation to a wider audience. Project method can also take the form of design and production in response to a challenge arising from human need. In both cases, children and young people have voice and agency, and activity is not just doing but 'educative activity'.

Storyline (Bell et al, 2007) is a very different 'open architecture' with a narrative rather than conceptual structure. Each storyline begins with a place, represented visually; the children invent characters and roles for themselves in that situation; the teacher moves the story forward by announcing or stimulating events and developments in a skeletal plot; at each node of the plot the pupils are invited to respond actively, and often in role, through drama, research, writing, maths, and so on. One of the earliest storylines, for studying the Vikings, starts with a painting of an empty bay. The pupils, intrigued, are told it is 1000 years ago, and are set to find out about the houses people lived in and how they used to live. They draw houses and stick them round the bay, becoming inhabitants of this settlement. One day the children come into class to see a boat on the water, which turns out to be a Viking longship. 
Storyline can take many shapes and curricular purposes. One of my Scottish teaching students invented one about a sleepy fishing village called Kilgallon, where some pupils spot a small drill boring for oil on their school field. They become participants and protagonists in a storyline which involves substantial social change and numerous economic and political dilemmas. A Norwegian school devised the storyline Rainbow Street, based in a multi-ethnic district of Oslo: the students become immigrants and refugees from many countries. They learn something of what it feels like to encounter racist attitudes, civic obstructions, religious bigotry, as well as to organise collective democratic action. In all these situations, learners use their own life experiences as a resource but move out to explore a new situation, not in the abstract but as rounded human beings.

'Open architectures' provide opportunities to pursue progressive principles of respecting the child's pace of development, experiential learning, social justice and democratic citizenship. They can be pursued within a school subject, or as cross-curricular activity on special learning days or weeks. They are, of course, not the only way to bring the child back in.

\section{Conclusion: bringing the child back in}

Children and young people in England are carrying the weight of a curriculum and assessment model which represents a fusion of neo-liberal and neoconservative demands. On the one hand, their integrity as growing individuals is obscured by the demand that they be made employment-ready as quickly and efficiently as possible; on the other, their own lives and experiences are eclipsed by a view of knowledge as fixed and remote. We need to insist on space for the growing child to come into authentic relationship with a cultural inheritance. As educators, our challenge is to bring the child back in.

In the present situation in England, under top-down pressure, the temptation for teachers is always to stay safely within the narrow confines of a lesson plan, to do yet another literacy exercise, to transmit pre-processed knowledge from the front, to stay on the tramlines. However efficiently such teaching is conducted, the lives of the children will remain unseen, untouched, unfelt, invisible even to themselves. Learning can be an alienated, alienating activity: do this because it might be in the exam, hand it in after an hour, and you'll get a grade or mark.

The lives of children, and particularly those in poverty and ethnic minorities, are missing in the current National Curriculum documents; young people are absent not just as individuals but collectively, as social, cultural, historical experience. Bringing the child back in does not mean intellectual sloppiness or inefficiency in sharing knowledge. It means stimulating the learners' commitment through self-activity - a sustained engagement in deeper, more critical, more creative forms of learning.

Finally, consider the relevance of all this to young people growing up in poverty. Although all children are being subjected to the consequences of 
league tables and a punitive inspection regime, this particularly affects schools in disadvantaged areas. Young people in such schools are more likely to experience the thin gruel of 'pedagogies of poverty' (Haberman, 1991). To overcome this, it is essential to reconnect to young lives, to bring the children back in.

\section{References}

Adamson, J. (1971) Pioneers of Modern Education. New York: Teachers College Press.

Ball, S. (2013) Foucault, Power and Education. London: Routledge.

Bell, S., Harkness, S. \& White, G. (Eds) (2007) Storyline Past, Present and Future. Glasgow: University of Strathclyde Press.

Bowen, H. (1903) Froebel and Education by Self-activity. London: Heinemann.

Department for Education (DfE) (2013) More Great Childcare: raising quality and giving parents more choice. London: DfE.

Dewey, J. (1902/1966) The Child and the Curriculum, in F. Garforth (Ed.) Selected Educational Writings. London: Heinemann.

Dewey, J. (1938/2015) Experience and Education. New York: Free Press.

Foucault, M. (1977) Discipline and Punish: the birth of the prison. London: Allen Lane.

Haberman, M. (1991) The Pedagogy of Poverty versus Good Teaching, Phi Delta Kappan, 73(4), 290-294.

Heathcote, D. \& Bolton, G. (1995) Drama for Learning: Dorothy Heathcote's Mantle of the Expert approach to education. London: Pearson.

Lawrence, E. (Ed.) (1969) Friedrich Froebel and English Education. London: Routledge \& Kegan Paul.

Lawson, J. \& Silver, H. (1973) A Social History of Education in England. London: Methuen.

Reclaiming Schools (18 January 2016) The Delusions of Baseline Testing. https://reclaimingschools.org/2016/01/18/the-delusions-of-baseline-testing

Reclaiming Schools (29 April 2016) Primary Tests: a barrier to real learning. https://reclaimingschools.org/2016/04/29/primary-tests-a-barrier-to-reallearning/

Roberts-Holmes, G. \& Bradbury, A. (2016) Reception Baseline Assessment. Occasional Paper 8. London: TACTYC. http://tactyc.org.uk/wpcontent/uploads/2016/06/Occ-Paper-8-Roberts-Holmes-PDF.pdf

Roe, N. (1997) John Keats and the Culture of Dissent. Oxford: Oxford University Press.

Sinclair, J. \& Coulthard, M. (1975) Towards an Analysis of Discourse. Oxford: Oxford University Press.

Stewart, W. \& McCann, W. (1967) The Educational Innovators, 1750-1880. London: Macmillan. http://dx.doi.org/10.1007/978-1-349-00531-4

Undervisningsministeriet - Folkeskoleafdelingen (1995) Samfundsfag (Faghæfte 5). Copenhagen: Undervisningsministeriet.

Vygotsky, L. (1978) Mind in Society: the development of higher psychological processes. Cambridge, MA: Harvard University Press. 
Terry Wrigley

Wrigley, T. (2005) Another School is Possible: learning from Europe, FORUM, 47(2), 223-232. http://dx.doi.org/10.2304/forum.2005.47.2.14

Wrigley, T. (2007) Projects, Stories and Challenges: more open architectures for school learning, in S. Bell, S. Harkness \& G. White (Eds) Storyline Past, Present and Future. Glasgow: University of Strathclyde Press.

Wrigley, T. (2014) The Politics of Curriculum in Schools. London: Centre for Labour and Social Studies. http://classonline.org.uk/docs/2014_Policy_Paper_-

_The_politics_of_curriculum_in_schools.pdf

Wrigley, T., Thomson, P. \& Lingard, B. (Eds) (2012) Changing Schools: alternative ways to make a world of difference. London: Routledge.

TERRY WRIGLEY is Visiting Professor at Northumbria University and helps to edit the reclaimingschools.org blog. He has long-standing concerns with the direction of policy in English schools, and the need to keep alternatives alive. His most recent book is Living on the Edge: retbinking poverty, class and schooling (London: Peter Lang). Correspondence: terrywrigley@gmail.com 